\title{
Mikroglial Toll-benzeri Reseptörlerin Alzheimer ve Parkinson Hastalıklarındaki Rolü
}

\section{The Role of Microglial Toll-like Receptors in Alzheimer's and Parkinson's Disease}

\author{
$1-2$ \\ Dilara NEMUTLU SAMUR, Gül ÖZBEY \\ 1 Akdeniz Üniversitesi Tıp Fakültesi, Tıbbi Farmakoloji Anabilim Dalı, ANTALYA, Türkiye \\ 2 Alanya Alaaddin Keykubat Üniversitesi Tıp Fakültesi, Tıbbi Farmakoloji Anabilim Dalı, ANTALYA, Türkiye
}

Yazışma Adresi

Correspondence Address

Dilara NEMUTLU SAMUR

Alanya Alaaddin Keykubat

Üniversitesi Tıp Fakültesi, Tıbbi

Farmakoloji Anabilim Dall,

ANTALYA, Türkiye

dilaranemutlu@gmail.com

Geliș tarihi / Received : Mar 13, 2020 Kabul tarihi / Accepted : Tem 26, 2020 Elektronik yayın tarihi : Eyl 01, 2021

Online published

Bu makalede yapılacak atıf:

Cite this article as:

Nemutlu Samur D, Özbey G.

Mikroglial Toll-benzeri

Reseptörlerin Nörodejeneratif

Hastalıklardaki Rolï

Akd Tip D / 2021; 7(3):448-456

Dilara NEMUTLU SAMUR

ORCID ID: 0000-0003-2630-6182 Gül ÖZBEY

ORCID ID: 0000-0002-3616-0052

\section{ÖZ}

Patern tanıma reseptörleri içinde en iyi tanımlanmış olan Toll-benzeri reseptörler, santral sinir sisteminde "makrofaj benzeri" fonksiyona sahip mikroglia hücrelerinde bulunurlar. Amiloid-beta $(\mathrm{A} \beta)$ proteini ve agrege $\alpha$-sinüklein gibi hasarla ilişkili moleküler motifleri tanıyan Toll-benzeri reseptörler, mikroglia hücrelerinin proinflamatuar fenotipe kaymasına neden olarak ve tümör nekroz faktör-alfa (TNF- $\alpha$ ), interlökin (IL)-1, IL-6, IL-12 gibi proinflamatuar mediyatörler aracıllı̆ıyla inflamasyonu tetikler. Nörodejeneratif hastalıklarda mikroglial Toll-benzeri reseptör aracılı sinyalizasyonun önemli bir role sahip olduğu gösterildiği için Alzheimer ve Parkinson hastalıklarında (i) aşılar, (ii) küçük moleküllü inhibitörler, (iii) var olan ilaçların yeni bir endikasyon için kullanılması ve (iv) doğal bileşikler gibi Toll-benzeri reseptörleri hedef alan yeni tedavi yaklaşımları bulunmaktadır. Preklinik çalışmalarda başarılı sonuçlar göstermiş olan ilaç adaylarının birçoğu klinik fazlarda aynı başarıyı yakalayamamıştır. Buna rağmen, Toll-benzeri reseptörler ve sinyal yolakları üzerinde etkili moleküllerle ilgili çalışmaların sayısı artmaya devam etmektedir.

\section{Anahtar Kelimeler:}

Mikroglia, Toll-benzeri reseptörler, Alzheimer hastalığı, Parkinson hastalı̆̆

\begin{abstract}
Toll-like receptors, the best defined among the different pattern recognition receptors, are found on microglia cells that have a "macrophage-like" function in the central nervous system. Toll-like receptors that recognize damage-related molecular motifs such as amyloid-beta $(\mathrm{A} \beta)$ protein and aggregated $\alpha$-synuclein, trigger inflammation via switching the microglial phenotype to proinflammatory side and releasing proinflammatory mediators such as tumor necrosis factor-alpha (TNF- $\alpha$ ), interleukin (IL)-1, IL-6, IL-12. Since Toll-like receptor-mediated signaling has been shown to play an important role in neurodegenerative diseases, there are new treatment approaches targeting Toll-like receptors including (i) vaccines, (ii) small molecule inhibitors, (iii) use of existing drugs for a new indication and (iv) use of natural compounds. Although many compounds have shown promising results in preclinical studies, they have not achieved the same success in clinical trials. However, the studies with compounds targeting Toll-like receptors and signaling cascades are continuing to increase.
\end{abstract}

\section{Keywords:}

Microglia, Toll-like receptors, Alzheimer's disease, Parkinson's disease 
Nemutlu Samur D. ve Özbey G.

\section{Santral sinir sisteminde doğal immünite}

Mikroglia hücreleri, santral sinir sistemi (SSS)'nde "makrofaj benzeri" fonksiyona sahip özelleşmiş glia hücreleridir. SSS'de mikroçevrenin korunmasından ve hasara karşı lokal immün yanıttan sorumludurlar (1). Fizyolojik koşullar altında istirahat halinde bulunan mikroglia hücreleri, SSS mikroçevresindeki değişikliklerle aktive hale gelir. "Mikrogliaların klasik M1 (proinflamatuar) fenotipi tümör nekroz faktör-alfa (TNF- $\alpha$ ), interlökin (IL)-1, IL-6, IL-12 gibi sitokinlerin yanı sıra süperoksit, nitrik oksit ve reaktif oksijen türleri (Reactive oxygen species, ROS)'nin salıverilmesine neden olarak proinflamatuar yanitı tetikler (2).Proinflamatuar moleküllerin salıverilmesi, endotel hücreleri arasındaki sıkı kavşak proteinlerinin internalizasyonu veya degradasyonu sonucu kan-beyin bariyerinde permeabilitede ve anjiyogenezde artışa yol açar (1). KBB'nin bozulması, monositler/makrofajlar, nötrofiller ve T hücreleri dahil olmak üzere diğer immün hücrelerin inflamatuar bölgeye göçüne neden olur (3). $\mathrm{Bu}$ inflamatuar süreç kontrol edilemez veya baskılanamazsa, SSS'nin yerleşik hücreleri zarar görebilir ve doku hasarı meydana gelebilir (3).

\section{Toll-benzeri reseptörlerin tanımı ve sinyal yolakları}

Konak savunması, patojenlerin üzerinde yer alan karakteristik paternlerin tanınması ile başlar. Toll-benzeri reseptör (Toll-like receptors, TLR)'lerin de dahil olduğu patern tanıma reseptörleri (PTR), inflamatuar koşullardaki konakçı hücreleri tarafından üretilen çeşitli PAMP (pathogen-associated molecular pattern, patojenle ilişkili moleküler motif) ve DAMP (damage-associated molecular pattern, hasarla ilişkili moleküler motif)'ların tanınmasında rol oynar (3). Birçok uyaran, mikroglialarda bulunan TLR'lerin aktivitesini modüle ederek mikrogliaların fenotipini değiştirebilir ve nörodejeneratif süreçlerin tetiklenmesine ya da ilerlemesine neden olabilir (4). Drosophila melanogaster'de ilk kez tanımlanmasindan günümüze kadar TLR'lerin, insanda 10 adet (TLR1 TLR10), farede ise 13 adet TLR (TLR1 - TLR13) alt tipi belirlenmiştir (5). TLR 1, 2, 4, 5 ve 6 hücre yüzeyinde eksprese edilerek patojenle ilişkili molekülleri algılarken, TLR 3, 7, 8 ve 9 hücre içinde, esas olarak endozomlarda yerleşmiştir ve RNA/DNA gibi nükleik asitleri tespit etmekte$\operatorname{dir}(3)$.

TLR yapısal olarak üç ana bölümden oluşur: Lösin zengin tekrarlar kısmı (leucine-rich repeats, LRR), transmembranal kısım ve sitoplazmik toll-benzeri/interlökin 1 kısmı (TIR) (Şekil 1).

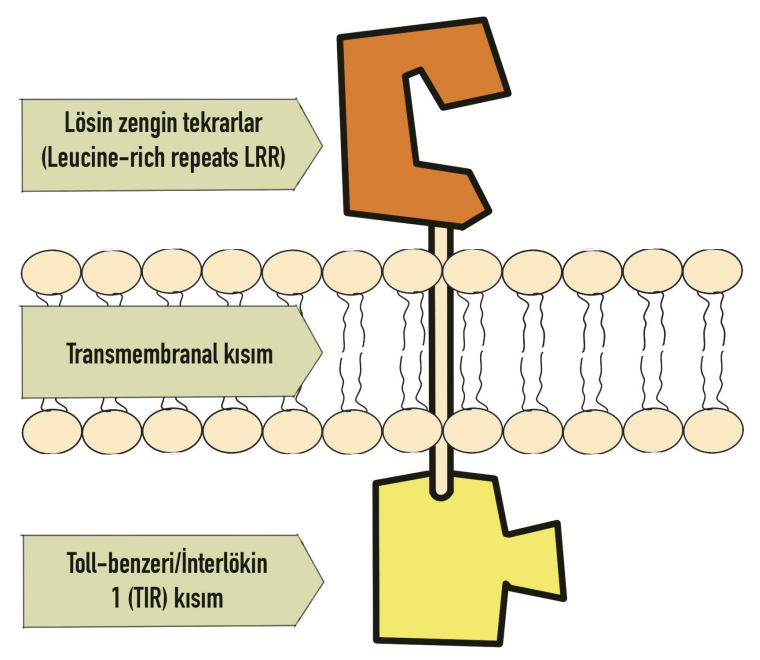

Şekil 1:

Toll-benzeri reseptörün kısımları. Lösin zengin tekrarlar kısm1 (leucine-rich repeats, LRR) ligand 1 tanır, Toll-benzeri/Interlökin 1 (TIR) kısmı adaptör proteinler ile etkileşime girerek sinyalizasyon kaskadını başlatır.

LRR motifi ligandın tanınmasından sorumluyken, TIR alanı sinyal transdüksiyon adaptörleri ile etkileşime girerek sinyalizasyon kaskadını başlatır (6). TLR'ler tarafından başlatılan sinyalizasyon, hücre içinde MyD88 (Myeloid differentiation primary response 88, Miyeloid Farklılaşma Primer Yanıt proteini 88) bağımlı ve MyD88 bağımsı/TRIF (TIR-domain-containing adapter-inducing interferon- $\beta$, TIR bölgesi içeren interferon- $\beta$ salıverilimini indükleyen adaptör) bağımlı olmak üzere iki farklı yolağ 1 aktive ederek aktivatör protein 1 (AP-1), nükleer faktör kappa-B (NF- $\mathrm{B})$, ve interferon düzenleyici faktör (Interferon regulatory factor, IRF)'ler gibi transkripsiyon faktörlerinin aktivasyonunu sağlar (Şekil 2) (7). 


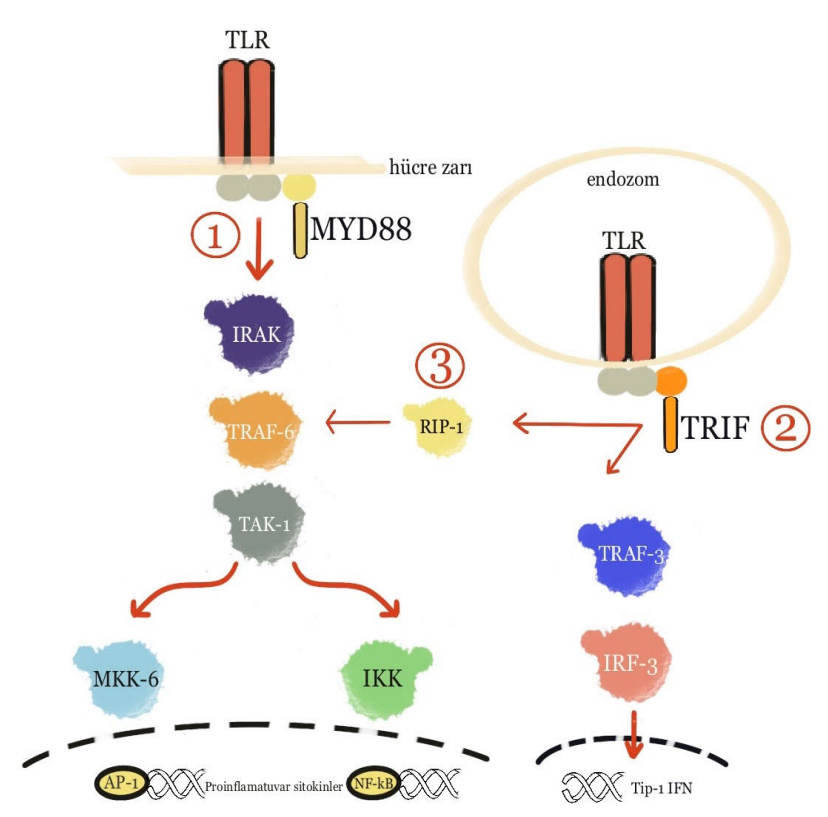

Şekil 2:

Toll-benzeri reseptör sinyalizasyon kaskadı. (1) MyD88-bağımlı yolak. TLR'ye ligand bağlandığında TIR bölgesi dimerizasyona uğrayarak MyD88'in bağlanması için gerekli konformasyonel değişiklikler meydana gelir. MyD88'in TIR bölgesi TLR'nin TIR bölgesi ile etkileşerek sinyalizasyon kaskadını tetikler. Bu etkileşim sonucu fosforile olan IRAK, TRAF-6'y1 aktive eder. TRAF-6'nın TAK-1'i aktive etmesi ile MKK-6 ve IKK aktive olur ve AP-1 ve NF-kB gibi transkripsiyon faktörlerinin nükleusa translokasyonu gerçekleşir. (2) Endozomlarda yer alan TLR'ler tarafindan kullanılan MyD88 bağımsız yolakta ise adaptör protein olarak TRIF yer alır ve sırasıyla TRAF-3 ve IRF-3 aktivasyonu gerçekleşir. Bu aktivasyon sonucu nükleusta anti-inflamatuar özellikteki Tip-I IFN'ların sentezi tetiklenir. (3) $\mathrm{Bu}$ yolakta ayrıca RIP-1 aktivasyonu aracılığıyla proinflamatuar sitokinlerin sentezi de tetiklenebilir. AP-1: Aktivatör protein 1, IкK: İnhibitör kappa-B kinaz; IRAK: Interleukin-1 receptor-associated kinase 1, İnterlökin-1 reseptörü ile ilişkili kinaz; IRF-3: Interferon regulatory factor 3, İnterferon düzenleyici faktör 3; MKK-6: MAP kinaz kinaz 6; MyD88: Myeloid differentiation primary response 88 , Miyeloid farklılaşma primer yanıt proteini 88 ; NF-кB: Nükleer faktör kappa-B; RIP-1: Receptor interacting protein 1, Reseptörle etkileşen protein 1; TAK-1: Transforming growth factor $\beta$-activated kinase 1, Transforme Edici Büyüme Faktörü Beta ile Aktive Olan Kinaz-1; Tip-1 IFN: Tip-1 İnterferon; TIR: Toll-like/İnterlökin 1 reseptörü, TLR: Toll-like receptor, Toll-benzeri reseptör; TRAF-3: TNF Receptor Associated Factor 3, TNF-reseptör ilişkili faktör 3; TRAF-6: TNF Receptor Associated Factor 6, TNF-reseptör ilişkili faktör 6; TRIF: TIR-domain-containing adapter-inducing interferon- $\beta$, TIR bölgesi içeren interferon- $\beta$ salıverilimini indükleyen adaptör.
TLR'nin ekstraselüler kısmı aktive olduğunda TIR bölgesi dimerizasyona uğrayarak MyD88'in bağlanması için gerekli konformasyonel değişiklikler meydana gelir. MyD88'in TIR alanı TLR'nin TIR alanı ile, amino $(\mathrm{N})$ terminali ise IL-1R-ilişkili kinaz (Interleukin-1 receptor-associated kinase 1, IRAK) proteini ile etkileşir. Bu etkileşim sonucu fosforile olan IRAK, TNF-reseptörü ile ilişkili faktör 6 (TNF Receptor Associated Factor 6, TRAF-6)'y1 aktive eder. TRAF-6'nın transforme edici büyüme faktör beta ile aktive olan kinaz-1 (transforming growth factor $\beta$-activated kinase 1, TAK-1)' $\mathrm{i}$ aktive etmesi ile inhibitör kappa-B kinaz (IкK) ve MAP kinaz kinaz 6 (MKK-6) aktive olur (6). TRIF yolağı olarak da adlandırılan MyD88 bağımsız yolak, TLR ligandları tarafından stimüle edildiğinde, TRIF molekülünü bağlayarak TNF-reseptörü ile ilişkili faktör 3 (TNF Receptor Associated Factor 3, TRAF-3) ve IRF-3'ün aktivasyonuna ve antiinflamatuar nitelikteki tip-1 interferon (IFN)'ların üretimine yol açar (6).

\section{Alzheimer hastalığı ile ilişkili nöroinflamasyonda Toll-benzeri reseptörler} Alzheimer hastalığı (AH), özellikle serebral korteks ve hipokampustaki piramidal nöronların ölümü nedeniyle gelişen bellek kaybı ve diğer bilişsel bozukluklar ile karakterize, ilerleyici nörodejeneratif bir hastalıktır (3). Moleküler belirteçleri, amiloid-beta $(\mathrm{A} \beta)$ peptid agregatlarından oluşan ekstraselüler $A \beta$ plaklar ve hiperfosforillenmiş tau proteininden zengin intraselüler nörofibriler yumaklardır (3). Yakın zamanda yapılan çalışmalarda TLR'lerin AH'nin patogenezinde ve ilişkili nöroinflamasyonda önemli bir rol oynadığı gösterilmiştir.

TLR-2, nörodejeneratif hastalıklar açısından en çok çalışılan TLR'lerdendir (4). Rangasamy ve ark., hem AH hastalarının postmortem beyin dokularında hem de transgenik 5xFAD farelerde, hipokampus ve korteks dokularında TLR-2 ve MyD88 ekspresyonlarının arttığını göstermiştir (8). TLR-2 blokajının $A \beta$ ile indüklenen proinflamatuar sitokinlerin salıverilmesi ve nöronal hücre hasarını nötralize ettiği rapor edilmiştir (9). Benzer şekilde, mutant genler eksprese eden APP/PS1 farelerde TLR-2 blokajının glial hücre reaktivitesini ve $A \beta$ agregasyonunu azalttığını ve bilişsel performansta iyileşme sağladığ1 da gösterilmiştir (10). Ayrıca, TLR2-/organotipik hipokampus kültürlerinin $\mathrm{A} \beta$ ile indüklenen fosforlanmış tau ekspresyonuna direnç gösterdiği gözlenmiş ve TLR-2 blokajının taupatileri hafifletebileceği bildirilmiştir (11). Liu ve ark., TLR-2'yi endojen olarak eksprese etmeyen insan embriyonik böbrek hücrelerinde (HEK293) TLR-2 ekspresyonu indüklendiğinde hücrelerin A $\beta-42$ 'ye yanıt verdiğini ve başka bir transgenik AH modeli olan APP23 farelerde, mikroglia hücrelerinde TLR-2 eksikliğinin inflamatuar M1 fenotipini antiinflamatuar M2 fenotipine kaydırdığını göstermişlerdir (12). Bu çalışmalar, TLR-2 aktivasyonunun SSS'de inflamasyona ve nörodejenerasyona aracılık edebileceğini ve TLR-2 fonksiyonunun inhibe edilmesinin hastalığın ilerlemesini yavaşlatma potansiyeli olabileceğini göstermekle birlikte TLR-2'nin AH'deki rolü tartışmalıdır. Chen ve ark., TLR-2 aktivasyonunun, A $\beta-42$ 
peptidinin mikroglialardaki formil peptid reseptör-benzeri 1 gibi kemotaktik peptid reseptörleri tarafından alınmasını arttırdığını göstermiştir (13). Richard ve ark., TLR-2 geni silinmiş APP/PS1 farelerin beyin dokularında A $\beta 1-42$ seviyelerinin arttığını ve uzaysal ve bağlamsal bellek bozukluklarının hızlandığını göstermişlerdir (14). Son olarak Heshmati-Fakhr ve ark., mikroglianın zayıf bir TLR-1/2 agonisti ile stimülasyonunun oligomerik $A \beta$ 'ya karşı nöroproteksiyona aracılık edebileceği düşünülen IFN- $\beta$ ekspresyonunu arttırdığını göstermiştir (15). Bu veriler, TLR-2'nin, toksik A $\beta$ 'nın immün hücreler tarafından temizlenmesi için endojen bir reseptör görevi gördüğünü göstermektedir.

$\mathrm{AH}$ hastalarının beyin dokularında sağlıklı gönüllülerle kıyaslandığında, TLR-4 mRNA ekspresyonlarında bir artış eğilimi olduğu gözlenmiștir (4). TLR-4 mutant transgenik farelerin beyin dokularında, TNF- $\alpha$, IL-1 $\beta$, IL-10 ve IL-17 seviyeleri, TLR-4 yabanıl tip farelere göre daha yüksek bulunmuş ve agrege $A \beta$ 'nın neden olduğu mikroglial aktivasyonun azaldığ ve proinflamatuar sitokin üretiminin anlamlı şekilde düştügü gösterilmiştir (16). İntraserebroventriküler (i.c.v.) A $\beta$ oligomerleri enjekte edilen C57 farelerde selektif TLR-4 antagonisti uygulamasının bellek fonksiyonlarını iyileştirdiği, TLR-4 geni silinmiş farelerde glial aktivasyonun olmadığ ve bellek fonksiyonlarının bozulmadığı gösterilmiştir (17). TLR-2'ye benzer şekilde, TLR-4'ün de AH patogenezi ve ilerlemesinde iki yönlü etkileri olduğu düşünülmektedir. Düşük doz TLR-2 ve TLR-4 ligandlarının, A $\beta$ toksisitesine maruz kalan sıçanların uzaysal ve çalışan bellek fonksiyonlarındaki bozulmaları iyileştirdiği; hipokampus dokusunda A $\beta$ tarafından bozulan uzun süreli potansiyalizasyonu onardığı; TNF- $\alpha$ seviyelerini ve $A \beta$ agregatlarını azalttığı; antiinflamatuar sitokinlerin (TGF-1 $\beta$, IL-10) ve mikroglia belirteci arginaz 1'in seviyelerini arttırdığı ve hipokampal mikrogliaların antiinflamatuar fenotip (M2) yönünde polarizasyonunu arttırdığ1 gösterilmiştir (18). TLR-4 mutant transgenik AH farelerde, 5. ayda serebral $A \beta$ yükünde yabanıl tip farelere göre bir farklılık görülmemiş, 9. ayda mikroglial aktivasyon azalmış, $A \beta$ birikimi artmış ve bilişsel fonksiyonlarda düşüş meydana gelmiştir (19). Hastalığın erken dönemini temsil eden bu sonuçlar, TLR-4'ün $A \beta$ birikiminin başlamasından sorumlu olmadığını ve $A \beta$ birikimleri başladığında TLR-4 sinyalinin $A \beta$ agregatlarını azaltmak ve bilişsel işlevleri $A \beta$ aracılı nörotoksisiteden korumak amacıyla mikrogliaları aktif hale getirdiğini göstermektedir (19). Dolayısıyla TLR-4'ün AH'deki rolünün hastalığın evresine bağlı olarak değiştiğ düşünülmektedir. AH'nın ilk evrelerinde TLR4'ün aktivasyonu A $\beta$-klerensini arttırırken, ileri evrelerde TLR4 A $\beta$ agregasyonunu hizlandirmaktadır (3).

TLR-2 ve TLR-4'e ek olarak, TLR-9 da hem mikroglialarda hem de nöronlarda eksprese edilmektedir (3). TLR-9 sinyalizasyonunun sarko/endoplazmik retikulum $\mathrm{Ca}^{2}$-ATPaz-2 (SERCA2) inhibisyonu aracılığıyla mitokondride ATP sentezini modüle ederek nöronları stresten koruyabileceği gösterilmiştir (20). Ayrıca, TLR-9 geni silinmiş farelerdeki pre ve postsinaptik defektlerin, nöromüsküler kavşakta fonksiyonel ve morfolojik değişikliklere neden olarak son plak potansiyelinin frekansında ve amplitüdünde artışa yol açması,
TLR-9'un sinaptik plastisitede rolü olabileceğini ortaya koymuştur (21). Bunun yanı sıra, TLR-9 agonistleri olarak işlev gören, bakteriyel ve viral DNA'ların ortak yapısal özellikleri olan, ancak omurgalı genomunda nadir görülen sitozin-fosfat-guanin ( $\mathrm{CpG}$ ) motiflerinin hedeflenmesi, $\mathrm{AH}$ transgenik fare modelinde hem $A \beta$ hem de tau patolojilerini azaltmış ve bilişsel bozuklukları iyileştirmiştir (22).

Son yıllarda, bazı TLR'lerin mikroglia yüzeyinden ayrıldığın$\mathrm{da}$, "tuzak reseptörler" olarak hareket edebilecekleri ve A $\beta$ plaklarının birikmesini azaltabilecekleri öngörülmektedir. $\mathrm{Bu}$ bağlamda, Chakrabarty ve ark., yapmış oldukları çalışmada, TLR-5' in hücre dışında kalan kısmını (ectodomain) eksprese eden virüs kaynaklı AH fare modelinde, çözünebilir TLR-5'in, A $\beta$ 'ya bağlanarak inflamasyona yol açan hücresel sinyal yolaklarını başlatmadan $A \beta$ agregasyonunu sınırlayan "tuzak reseptörleri" olarak işlev görebileceğini göstermiştir (23).

\section{Alzheimer hastalığında Toll-benzeri reseptör hedefli tedavi yaklaşımları}

Son yıllarda yapılan çalışmalar AH'de doğal immüniteyi A $\beta$ plaklarının hem temizlenmesinde hem de agregasyonunda yer alan iki ucu keskin bir bıçak olarak nitelendirdiği için en iyi terapötik yaklaşımın, spesifik TLR agonistleri ve antagonistlerinin kombine edilerek mikroglial aktivitenin optimizasyonunu sağlamak olduğunu savunmaktadır (24). AH patogenezinin erken evresinde, glial fagositik ve nöronal otofajik fonksiyonlar arttırılmak istendiğinde, spesifik TLR agonistleri kullanılabilir. Artmış nöroinflamasyon ve fibriler $\mathrm{A} \beta$ kümelenmeleri ile ilişkili aşırı aktif mikroglial hücreler ile karakterize geç fazda ise, spesifik proinflamatuar sitokin üretimini azaltmak için TLR antagonistleri yararlı olabilir (24). Ancak, literatürde mikroglialar üzerindeki TLR'ler tarafindan modüle edilen etkiler ve bu etkilere aracılık eden spesifik yolaklar hakkında halen çok az bilgi mevcuttur ve daha fazla çalışmaya ihtiyaç duyulmaktadır (4).

AH'nin A $\beta$ plakların ana bileşeni olan ve beyinde biriken agrege A $\beta$ 'ya karşı adaptif bir immün yanıt oluşturmak amacıyla aşılar üretilmeye çalışılmaktadır. $\mathrm{Bu}$ aşılardan ACI-24, hastanın immün sistemini, $A \beta$ plak birikimini önlemek ve plak klerensini arttırmak için oligomerik ve fibriler $A \beta$ proteinlerini spesifik olarak hedefleyen antikorlar üretmesini uyarmak üzere tasarlanmıştır (25). Çift transgenik APP/PS1 farelerinde iki intraperitoneal ACI-24 aşılamasından sonra A $\beta$ plaklarda azalma ve bellek restorasyonunda önemli iyileşmeler olduğunu ortaya koyulmuştur (26). Hafif-orta düzeydeki AH hastalarında ACI-24'ün güvenlilik, tolere edilebilirlik, immünojenisite ve etkililiğinin inceleneceği bir Faz II çalışması 2018 yılında başlamıştır (EudraCT Number: 2018-000445-39). Ocak 2016'da ACI-24, orta yaşta beyinde A $\beta$ birikimi ve demansa yol açan genetik bir durum olan Down sendromunda $\mathrm{AH}$ tedavisi için değerlendirilmesi için çalışma planlanan ilk anti-A $\beta$ aşı olmuştur (Faz I çalışması devam ediyor, NCT02738450). Seçilmiş TLR agonistleri A $\beta$ 'ya karş1 aşılamada adjuvan olarak kullanılmaktadır (24). Örneğin ACI-24'te adjuvan olarak kullanılan monofosforil lipid A (MPLA) TLR-4'ün TRIF-yanlı agonistidir (27). MPLA 
TLR-4'e bağlandığında TRAM/TRIF sinyal yolağını stimüle ederken, MyD88 yolağını bloke eder ve daha az toksisite oluşturur (27). TLR-9 agonisti motifi olan CpG-oligodeoksinükleotidleri (CpG-ODN) de hali hazırda onaylanmış bir aşı adjuvanıdır (28). CpG-ODN motifi taşıyan bir peptit immünojeni içeren UB-311 adlı bir AH aşısı şu anda Faz II denemelerine tabi tutulmaktadır (NCT02551809). First-in-human Faz I çalışmasında UB-311, erken evre AH hastalarının kognitif fonksiyonlarında iyileşme sağlamıştır (29). Güvenlilik ve ilk etkililikte elde edilen pozitif sonuçlardan yola çıkarak, daha uzun vadeli güvenlilik, tolere edilebilirlik, immünojenisite ve etkinliği karakterize etmek için 2015 y1lında randomize, çift kör, plasebo kontrollü, 78 haftalık çok merkezli bir faz IIa çalışması (NCT02551809) başlatılmıştır. Hafif AH'li ve A $\beta+$ 45 hastaya 0,4 ve 12 . haftalarda uygulanacak başlangıç dozlarından sonra, 12 haftalık veya 24 haftalık aralıklarla ilave dozların verilmesi ve sonuçların değerlendirilmesi planlanmaktadır (29).

\section{Parkinson hastalığı ile ilişkili} nöroinflamasyonda Toll-benzeri reseptörler

Parkinson Hastalığı (PH), AH'den sonra en sık görülen ikinci nörodejeneratif hastalıktır. Striatal dopamin eksikliğine neden olan substantia nigra (SN)'daki dopaminerjik nöronların kaybı ve $\alpha$-sinüklein agregatları içeren inklüzyon cisimleri (Lewy cisimcikleri) karakterizedir (30). Yapılan çalıșmalar ve nörogörüntüleme sonuçları, sağlıklı bireylere kıyasla PH hastalarının beyinlerinde yaşla korele olarak mikroglial aktivasyonun arttığını göstermektedir (31).

Lewy cisimciklerinin ana bileşeni olan $\alpha$-sinüklein agregasyonunun mikroglial aktivasyonu indüklediği gösterilmiştir (32). Agrege $\alpha$-sinükleinin mikrogliayı nasıl aktive ettiği halen araştırılmakla birlikte, bir DAMP olarak çalıştığ ve mikroglia üzerindeki TLR'leri aktive ettiği düşünülmektedir (33). PH patogenezinde TLR'lerin rollerini araştıran çalışmaların çoğu TLR-2 ve 4'e odaklanmıştır, TLR-9 ile yapılan daha az sayıda çalışma bulunmaktadır (33).

PH hastalarının postmortem beyin dokularında TLR-2'nin arttığ1 ve TLR-2'nin amoeboid mikroglia ile birlikte lokalize olduğunun gösterilmesi, PH beyinlerinde TLR-2'nin aktif mikroglia tarafından artırıldığını düşündürmüştür $(34,35)$. İn vitro çalışmalar ve deneysel hayvan modellerinde yapılan in vivo çalışmalar da PH'nin patogenezinde ve progresyonunda TLR-2'nin rolü olduğunu göstermektedir. Endojen $\alpha$-sinüklein, TLR-2'ye bağlanarak mikroglial aktivasyonu tetiklemektedir (35). Ayrıca, nöronal hücrelerden hücre dış1 sıvıya salıverilen $\alpha$-sinükleinin, mikroglialar üzerindeki TLR-2'ye bağlanarak inflamatuar yanitları aktive eden endojen bir agonist gibi davrandığı gösterilmiştir (35). C57BL/6N farelerde $\alpha$-sinüklein oligomerlerinin i.c.v. uygulamasının glial hücre ve TLR-2 aracılı mekanizmalar aracılığıly bellek fonksiyonlarını bozduğu gösterilmiştir (36). TLR-2 aracılı sinyal yolağının baskılanmasının nöroprotektif olabileceği düşünülmektedir. Örneğin; 1-metil-4-fenil-1,2,3,6-tetrahidropiridin (MPTP) ile indüklenen $\mathrm{PH}$ fare modelinde, dayanıklılık egzersizlerinin TLR-2 ve ilişkili sinyal yolağını baskılayarak nöroprotektif etki sağladığı gösterilmiştir (37).
Anti-TLR-2 uygulamasının, $\alpha$-sinüklein transgenik PH/Lewy cisimcikli demans fare modelinde nöronal ve astroglial hücrelerde $\alpha$-sinüklein birikimini, nöroinflamasyonu, nörodejenerasyonu ve açık alan testindeki davranış bozukluklarını azalttığı gösterilmiştir (38). Ayrıca, TIR alanı içindeki bir cebi hedefleyen küçük molekül inhibitörleri tarafindan TLR-2 sinyalinin inhibisyonunun terapötik olarak anlamlı olabileceği in vitro ve in vivo olarak gösterilmiştir (39). TLR-2, PH'de de iki yönlü etkilere sahiptir: mikroglial aktivasyon ile nörotoksisiteyi indükleyebilir veya $\alpha$-sinükleinin temizlenmesi sağlayarak nöroprotektif etkiler gösterebilir (40). Nitekim TLR-2 geninde 22 baz çiftinin delesyona uğradığ $1-196-174$ del polimorfizminin, TLR-2'nin transkripsiyonel aktivitesinin azalmasına neden olarak PH riskini artırabileceği bildirilmiştir (41).

Çalışmalar, TLR-4'ün de $\alpha$-sinükleini bir DAMP olarak tanıdığını ve sonrasında immün yanıtın başlatılmasından sorumlu olduğunu göstermektedir. PH hastalarında, sağlıklı bireylere kıyasla SN, putamen ve dolaşımdaki monositlerde TLR-4 ekspresyonunun artmış olduğu gösterilmiştir (42). $\alpha$-sinükleine maruz bırakılan TLR-4-/- mikrogliaların, yabanıl tip mikroglialara (TLR4+/+) kıyasla daha az TNF- $\alpha$ ve ROS sentezlediği gösterilmiştir (43). Yabanıl tip C3H/OuJ farelerde MPTP uygulamasının TLR-4 ekspresyonunu artırdığı, TLR-4 geni silinen farelerde ise MPTP'nin neden olduğu dopaminerjik hücre ölümünün, mikroglial aktivasyonun ve motor bozuklukların azaldığı gösterilmiştir $(44,45)$. Campolo ve ark., bu motor bozuklukların, proinflamatuar sitokinlerin salıverilmesine neden olan multimerik protein kompleksleri olan inflamazomların aktivasyonunun inhibisyonu aracılığıyla azaldığını göstermiştir (45). Ancak, AH'de olduğu gibi PH'de de TLR-4'ün hem nöroprotektif hem de nörotoksik özellikleri rapor edilmiştir. Örneğin, Stefonova ve ark., BV2 mikroglialarda TLR-4 ablasyonunun $\alpha$-sinükleinin mikroglial fagositozunu bozduğunu göstermiştir. Aynı çalışmada, TLR-4 eksikliğinin, $\alpha$-sinükleini aşırı eksprese eden fare modelinde SN'deki dopaminerjik nöron kaybını ve motor bozuklukları artırdığı bildirilmiştir (46). TLR4-/- farelerde bazı beyin bölgelerinde $\alpha$-sinüklein mRNA'sının aşırı eksprese edilmesi, TLR-4'ün nöroproteksiyonda rol alabileceğini göstermiştir (47).

Literatürde PH patogenezinde TLR-9'un da rolü olabileceğine dair kanıtlar mevcuttur. TLR-9'un hem PH hastalarının hem de MPTP uygulanmış farelerin striatumlarında arttığ 1 gösterilmiştir (48). MPTP ile oluşturulan PH fare modelinde TLR-9 ablasyonunun SN'de dopaminerjik hücre ölümüne karş1 koruyucu olduğu gösterilmiştir (49). Araştırmacılar ayrıca TLR-9 arac1lı yanıtta glukokortikoid reseptörleri (GR)'nin düzenleyici bir rolü olduğunu ileri sürmüşlerdir. TLR-9 agonistinin kontrol ve GR silinmiş farelere uygulanması, GR silinmiş grupta daha belirgin bir dopaminerjik hücre kaybına yol açmıştır (49). GR'nin TLR-9 aracılı nörodejenerasyonda koruyucu bir rol oynayabileceği ileriki çalışmalarla doğrulanırsa, GR'leri PH tedavisinde yeni terapötik hedefler arasında yer alabilir (49). 


\section{Parkinson hastalığında Toll-benzeri reseptör hedefli tedavi yaklaşımları}

TLR ligandlarının büyük bir kısmı PH hayvan modellerinde çalışılmış olmakla birlikte, klinik çalışmaların sonuçları farklılıklar göstermektedir (33). Şimdiye kadar tanımlanan üç ana terapötik yaklaşım, (i) küçük moleküllü inhibitörler, (ii) ruhsatlı ilaçların yeni bir endikasyon için kullanılması (drug repurposing) ve (iii) bitkilerden saflaşttrılarak elde edilen kimyasal maddelerin kullanımını kapsamaktadır (33).

Küçük moleküllü inhibitörler, amfipatik özelliklere sahip, küçük boyutları ile hücre zarını kolayca geçerek TLR sinyal yolağında yer alan spesifik hücre içi adaptör proteinleri hedef alarak TLR sinyalini inhibe etme aktivitesine sahip olan kimyasal maddelerdir (50). Dzamko ve ark., TLR sinyal iletim yolundaki farklı proteinleri hedefleyen küçük moleküllü inhibitörleri kullanarak SHSY5Y insan nöroblastoma hücrelerinde TLR-2 aktivasyonu ile biriken $\alpha$-sinüklein agregatlarını önlemiştir (34). TLR-4'ün TIR kısmına reseptörü antagonize eden bir başka küçük moleküllü inhibitör TAK242 (resatorvid), Amyotrofik Lateral Skleroz ve Travmatik Beyin Hasarı hayvan modellerinde kullanılmış ve nöroinflamasyonu azalttığı gösterilmiştir (33). Hughes ve ark., nöron kültürlerinde TAK242'nin, $\alpha$-sinükleinin oluşturduğu oksidatif stresi ve hücre ölümünü azalttığını göstermiştir (51). TLR-1/2'nin selektif inhibitörü olan CU-CPT22'nin, $\alpha$-sinükleine maruz kalan mikroglialarda TNF- $\alpha$ üretiminde ve NF-кB'nin nükleusa translokasyonunda eşzamanlı bir azalmaya yol açtığı gösterilmiş olmakla birlikte (52) elde edilen sonuçlar in vivo çalışmalarla doğrulanmamıştır (33).

Nörodejeneratif hastalıkların tedavisine yönelik stratejiler arasında, diğer endikasyonlar için ruhsatlandırılmış ve tedavide kullanılmakta olan ilaçların, nörodejeneratif hastalıklardaki terapötik potansiyellerinin araştırılması (drug repurposing) da yer almaktadır (33). Örneğin, Dasu ve ark., anjiyotensin II AT1 reseptör blokörü olan kandesartan tedavisinin LPS ile indüklenen TLR-2/4 ekspresyonlarını azalttığını, TNF- $\alpha$, IL-1 $\beta$ ve IL-6 gibi proinflamatuar sitokinlerin salıverilmesini inhibe ettiğini hem insan monositlerinde in vitro olarak hem de C57BLJ/6 farelerde in vivo olarak göstermişlerdir (53). 2018 yılında yapılan çift-kör, plasebo kontrollü bir çalışmada, vinka alkaloidi vinkaminin yarı sentetik bir türevi olan ve NF-kB inhibisyonu aracilığıyla antiinflamatuar ve nöroprotektif etkiler gösteren vinposetinin; TLR-2, TLR-4, MyD88, NF-kB ve TNF- $\alpha$ ekspresyonlarında azalma, TLR-3 ve antiinflamatuar sitokinlerin ekspresyonlarında artış meydana getirerek mini mental durum değerlendirme skorlarında anlamlı bir artış sağladığı gösterilmiştir (54). Hiperlipidemi tedavisinde ve koroner kalp hastalığ ile serebrovasküler hastalıkların profilaksisinde yaygın olarak kullanılan statinlerin, antioksidan ve antiinflamatuar etkilerinin de olduğu, PH tedavisinde olumlu etkileri olabileceği ya da PH riskini azaltabileceği bildirilmiştir (55). 6-OHDA ile tedavi edilen mikroglial hücrelerde lovastatinin proinflamatuar sitokinleri inhibe ederek nöroprotektif etki oluşturduğu gösterilmiştir (56). Klasik bir hidroksimetilglutaril (HMG)-CoA redüktaz inhibitörü olarak bilinse de çalışmalar lovastatinin TLR-4 üzerinde antagonist etkilerinin de olduğunu göstermektedir (57).

Bitkisel ürünlerden saflaştırılarak elde edilen ve TLR-4 üzerinde antagonist etki gösteren maddeler arasında; Curcuma longa'dan elde edilen kurkumin, turpgiller ailesinde yer alan sebzelerden elde edilen sülforafan ve iberin, șerbetçiotu ve biradan elde edilen ksantohumol'dur (58). Yu ve ark., in vitro MPTP PH modelinde kurkumin ile ön tedavinin, astrosit aktivasyonunu, proinflamatuar sitokinlerin üretimini ve TLR-4 sinyal yolağının aktivasyonunu inhibe ettiğini göstermiştir (59). Ayrıca, Şizandra meyvesinden (Schisandra chinesnesis) izole edilen şizandrin $\mathrm{B}$, mikroglia-nöron

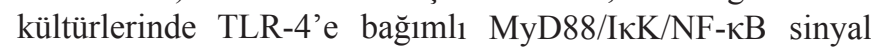
yolağını inhibe ederek nöroprotektif etkiler göstermiştir (60). Asiatik asit, Juglanin, D vitamini ve Quercetin'in antiinflamatuar özelliklere sahip olduğunun gösterildiği çalışmaların çoğunda, TLR ekspresyonlarının azaldığ 1 gösterilmiş ve bu doğal bileşiklerin nöroprotektif etkilerini TLR sinyal yolağının inhibisyonu aracıllığıla oluşturdukları öne sürülmüştür (33).

\section{Sonuçlar}

TLR'ler çok sayıda fizyolojik ve patofizyolojik mekanizmada yer alırlar. Hem endozomal hem de plazma membranındaki reseptörlerinin aktivasyonu, nörodejeneratif süreçlerin gelişiminde oldukça önemli role sahip olan mikroglia hücrelerinin aktivitelerini ve fenotiplerini modüle eder (4). Hem A $\beta$ proteininin hem de agrege $\alpha$-sinüklein formlarının tanınmasindan sorumlu olan TLR-2 ve TLR-4, AH ve PH'de en çok araştırılan TLR'lerdir $(24,33)$. Bununla birlikte, mikroglia tarafindan modüle edilen yolaklar hakkındaki mevcut bilgi halen kısıtlıdır ve nöroprotektif ilaçların geliştirilmesinde farmakolojik bir hedef potansiyeli taşıyan TLR'lerin, hastalıkların patofizyolojik süreçlerindeki rollerinin aydınlatılması için ileri çalışmalara ihtiyaç duyulmaktadır. $\mathrm{Bu}$ bağlamda, çeşitli TLR agonist/antagonistleri kullanılarak farklı tipteki TLR'lerin AH ve PH prognozundaki rolü aydınlatılabilir. Nörodejeneratif sürecin ilerleyişine katkıda bulunan TLR'lerin susturulmasina veya düzenleyici mekanizmaları tetikleyen TLR'lerin aktivasyonuna yönelik yapılacak çalışmalar, AH ve PH tedavisi için yeni moleküler hedeflerin araştırılmasında başarı sağlayabilir. Ayrıca, nörodejeneratif süreçte iki yönlü etkileri bulunan reseptör tiplerinin hangi koşullar altında hangi yolağı aktif hale getirdiğine dair elde edilebilecek yeni bulgular, çalışmalarda hastalığın temsil edilen farklı evrelerinden veya uygulanan protokollerden kaynaklı çelişkili sonuçları gidererek araştırmacılara daha güncel ve net bir bakış açısı sunacaktır. TLR-aracılı doğal immünite cevaplarıyla ilişkili erken nörodejeneratif mekanizmaları anlamaya yönelik yapılacak araştırmalar sayesinde, dejenerasyona uğramış nöronların rol aldığı ve hastalığın daha ileri dönemlerinde saptanabilen $A \beta$ ve $\alpha$-sinüklein patolojilerine erken dönemde müdahale edebilecek stratejilerin geliştirilmesinin önü açılabilir. 


\section{KAYNAKLAR}

1. Wesselingh R, Butzkueven H, Buzzard K, Tarlinton $\mathrm{D}$, O'Brien TJ, Monif M. Innate Immunity in the Central Nervous System: A Missing Piece of the Autoimmune Encephalitis Puzzle? Front Immunol 2019; 10:2066.

2. Wang WY, Tan MS, Yu JT, Tan L. Role of pro-in flammatory cytokines released from microglia in Alzheimer's disease. Ann Transl Med 2015; 3(10):136.

3. Kumar V. Toll-like receptors in the pathogenesis of neuroinflammation. J Neuroimmunol 2019; s332:16-30.

4. Fiebich BL, Batista CRA, Saliba SW, Yousif NM, de Oliveira ACP. Role of Microglia TLRs in Neurode generation. Front Cell Neurosci 2018; 12:329.

5. Nie L, Cai SY, Shao JZ, Chen J. Toll-Like Receptors, Associated Biological Roles, and Signaling Networks in Non-Mammals. Front Immunol 2018; 9:1523.

6. Akira S, Takeda K. Toll-like receptor signalling. Nat Rev Immunol 2004; 4(7):499-511.

7. Vidya MK, Kumar VG, Sejian V, Bagath M, Krish nan G, Bhatta R. Toll-like receptors: Significance, ligands, signaling pathways, and functions in mam mals. Int Rev Immunol 2018; 37(1):20-36.

8. Rangasamy SB, Jana M, Roy A, Corbett GT, Kundu M, Chandra S, Mondal S, Dasarathi S, Mufson EJ, Mishra RK, Luan CH, Bennett DA, Pahan K. Selec tive disruption of TLR2-MyD88 interaction inhibits inflammation and attenuates Alzheimer's pathology. J Clin Invest 2018; 128(10):4297-312.

9. Udan ML, Ajit D, Crouse NR, Nichols MR. Toll-like receptors 2 and 4 mediate Abeta(1-42) activation of the innate immune response in a human monocytic cell line. J Neurochem 2008; 104(2):524-33.

10. McDonald CL, Hennessy E, Rubio-Araiz A, Keogh B, McCormack W, McGuirk P, Reilly M, Lynch MA. Inhibiting TLR2 activation attenuates amyloid accumulation and glial activation in a mouse model of Alzheimer's disease. Brain Behav Immun 2016; 58:191-200.

11. Su F, Bai F, Zhou H, Zhang Z. Reprint of: Microglial toll-like receptors and Alzheimer's disease. Brain Behav Immun 2016; 55:166-78.

12. Liu S, Liu Y, Hao W, Wolf L, Kiliaan AJ, Penke B, Rube CE, Walter J, Heneka MT, Hartmann T, Menger MD, Fassbender K. TLR2 is a primary receptor for Alzheimer's amyloid beta peptide to trigger neuroinflammatory activation. J Immunol 2012; 188(3):1098-107.

13. Chen K, Iribarren P, Hu J, Chen J, Gong W, Cho EH, Lockett S, Dunlop NM, Wang JM. Activation of Toll-like receptor 2 on microglia promotes cell uptake of Alzheimer disease-associated amyloid beta peptide. J Biol Chem 2006; 281(6):3651-9.

14. Richard KL, Filali M, Prefontaine P, Rivest S.
Toll-like receptor 2 acts as a natural innate immune receptor to clear amyloid beta 1-42 and delay the cognitive decline in a mouse model of Alzheimer's disease. J Neurosci 2008; 28(22):5784-93.

15. Heshmati-Fakhr N, Sotoodehnejadnematalahi F, Yousefi N, Sayyah M, Hosseini SM, Pourbadie HG. Triggering microglia through toll-like receptor 2 pathway induced interferon beta expression in cell and animal model of Alzheimer's disease. Neurore port 2018; 29(17):1456-62.

16. Jin JJ, Kim HD, Maxwell JA, Li L, Fukuchi K. Toll-like receptor 4-dependent upregulation of cytokines in a transgenic mouse model of Alzhei mer's disease. J Neuroinflammation 2008; 5:23.

17. Balducci C, Frasca A, Zotti M, La Vitola P, Mhillaj E, Grigoli E, Iacobellis M, Grandi F, Messa M, Colombo L, Molteni M, Trabace L, Rossetti C, Salmona M, Forloni G. Toll-like receptor 4-depen dent glial cell activation mediates the impairment in memory establishment induced by beta-amyloid oligomers in an acute mouse model of Alzheimer's disease. Brain Behav Immun 2017; 60:188-97.

18. Pourbadie HG, Sayyah M, Khoshkholgh-Sima B, Choopani S, Nategh M, Motamedi F, Shokrgozar MA. Early minor stimulation of microglial TLR2 and TLR4 receptors attenuates Alzheimer's disease-related cognitive deficit in rats: behavioral, molecular, and electrophysiological evidence.

Neurobiol Aging 2018; 70:203-16.

19. Song M, Jin J, Lim JE, Kou J, Pattanayak A, Rehman JA, Kim HD, Tahara K, Lalonde R, Fukuchi K. TLR4 mutation reduces microglial activation, increases Abeta deposits and exacerbates cognitive deficits in a mouse model of Alzheimer's disease. J Neuroinflammation 2011; 8:92.

20. Shintani Y, Drexler HC, Kioka H, Terracciano CM, Coppen SR, Imamura H, Akao M, Nakai J, Wheeler AP, Higo S, Nakayama H, Takashima S, Yashiro K, Suzuki K. Toll-like receptor 9 protects non-immune cells from stress by modulating mitochondrial ATP synthesis through the inhibition of SERCA2. EMBO Rep 2014; 15(4):438-45.

21. Patel V, Patel AM, McArdle JJ. Synaptic abnormali ties of mice lacking toll-like receptor (TLR)-9. Neuroscience 2016; 324:1-10.

22. Scholtzova H, Chianchiano P, Pan J, Sun Y, Goni F, Mehta PD, Wisniewski T. Amyloid beta and Tau Alzheimer's disease related pathology is reduced by Toll-like receptor 9 stimulation. Acta Neuropathol Commun 2014; 2:101.

23. Chakrabarty P, Li A, Ladd TB, Strickland MR, Koller EJ, Burgess JD, Funk CC, Cruz PE, Allen M, Yaroshenko M, Wang X, Younkin C, Reddy J, Lohrer B, Mehrke L, Moore BD, Liu X, Ceballos-Diaz C, Rosario AM, Medway C, Janus C, Li HD, Dickson DW, Giasson BI, Price ND, Younkin SG,

Ertekin-Taner N, Golde TE. TLR5 decoy receptor as a novel 
anti-amyloid therapeutic for Alzheimer's disease. J Exp Med 2018; 215(9):2247-64.

24. Gambuzza ME, Sofo V, Salmeri FM, Soraci L, Marino S, Bramanti P. Toll-like receptors in Alzhei mer's disease: a therapeutic perspective. CNS Neurol Disord Drug Targets 2014; 13(9):1542-58.

25. Grundman M, Kinney GG, Yuen E, Black R. Immu notherapy for Alzheimer's Disease. In: Anil K. Nair, Sabbagh MN, eds. Geriatric Neurology. 1st ed. New Delhi, India: John Wiley \& Sons, 2014:574-86.

26. Muhs A, Hickman DT, Pihlgren M, Chuard N, Giriens V, Meerschman C, van der Auwera I, van Leuven F, Sugawara M, Weingertner MC, Bechinger B, Greferath R, Kolonko N, Nagel-Steger L, Riesner D, Brady RO, Pfeifer A, Nicolau C. Liposomal vaccines with conformation-specific amyloid peptide antigens define immune response and efficacy in APP transgenic mice. Proc Natl Acad Sci U S A 2007; 104(23):9810-5.

27. Mata-Haro V, Cekic C, Martin M, Chilton PM, Casella CR, Mitchell TC. The vaccine adjuvant monophosphoryl lipid A as a TRIF-biased agonist of TLR4. Science 2007; 316(5831):1628-32.

28. Mirotti L, Alberca Custodio RW, Gomes E, Rammauro F, de Araujo EF, Garcia Calich VL, Russo M. CpG-ODN Shapes Alum Adjuvant Activity Signaling via MyD88 and IL-10. Front Immunol 2017; 8:47.

29. Wang CY, Wang PN, Chiu MJ, Finstad CL, Lin F, Lynn S, Tai YH, De Fang X, Zhao K, Hung CH, Tseng Y, Peng WJ, Wang J, Yu CC, Kuo BS, Frohna PA. UB-311, a novel UBITh((R)) amyloid beta peptide vaccine for mild Alzheimer's disease. Alzhei mers Dement (N Y) 2017; 3(2):262-72.

30. Poewe W, Seppi K, Tanner CM, Halliday GM, Brun din P, Volkmann J, Schrag AE, Lang AE. Parkinson disease. Nat Rev Dis Primers 2017; 3:17013.

31. Lecours C, Bordeleau M, Cantin L, Parent M, Paolo TD, Tremblay ME. Microglial Implication in Parkin son's Disease: Loss of Beneficial Physiological Roles or Gain of Inflammatory Functions? Front Cell Neurosci 2018; 12:282.

32. Zhang W, Wang T, Pei Z, Miller DS, Wu X, Block ML, Wilson B, Zhang W, Zhou Y, Hong JS, Zhang J. Aggregated alpha-synuclein activates microglia: a process leading to disease progression in Parkinson's disease. FASEB J 2005; 19(6):533-42.

33. Kouli A, Horne CB, Williams-Gray CH. Toll-like receptors and their therapeutic potential in Parkin son's disease and alpha-synucleinopathies. Brain Behav Immun 2019; 81:41-51.

34. Dzamko N, Gysbers A, Perera G, Bahar A, Shankar A, Gao J, Fu Y, Halliday GM. Toll-like receptor 2 is increased in neurons in Parkinson's disease brain and may contribute to alpha-synuclein pathology. Acta Neuropathol 2017; 133(2):303-19.

35. Kim C, Ho DH, Suk JE, You S, Michael S, Kang J,
Joong Lee S, Masliah E, Hwang D, Lee HJ, Lee SJ. Neuron-released oligomeric alpha-synuclein is an endogenous agonist of TLR2 for paracrine activation of microglia. Nat Commun 2013; 4:1562.

36. La Vitola P, Balducci C, Cerovic M, Santamaria G, Brandi E, Grandi F, Caldinelli L, Colombo L, Morgese MG, Trabace L, Pollegioni L, Albani D, Forloni G. Alpha-synuclein oligomers impair memory through glial cell activation and via Toll-like receptor 2. Brain Behav Immun 2018; 69:591-602.

37. Koo JH, Jang YC, Hwang DJ, Um HS, Lee NH, Jung JH, Cho JY. Treadmill exercise produces neuropro tective effects in a murine model of Parkinson's disease by regulating the TLR2/MyD88/NF-kappaB signaling pathway. Neuroscience 2017; 356:102-13.

38. Kim C, Spencer B, Rockenstein E, Yamakado H, Mante M, Adame A, Fields JA, Masliah D, Iba M, Lee HJ, Rissman RA, Lee SJ, Masliah E. Immuno therapy targeting toll-like receptor 2 alleviates neurodegeneration in models of synucleinopathy by modulating alpha-synuclein transmission and neuroinflammation. Mol Neurodegener 2018; 13(1):43.

39. Mistry P, Laird MH, Schwarz RS, Greene S, Dyson T, Snyder GA, Xiao TS, Chauhan J, Fletcher S, Toshchakov VY, MacKerell AD, Jr., Vogel SN. Inhibition of TLR2 signaling by small molecule inhibitors targeting a pocket within the TLR2 TIR domain. Proc Natl Acad Sci U S A 2015; 112(17):5455-60.

40. Rietdijk C, van Wezel R, Garssen J, Kraneveld A. Neuronal toll-like receptors and neuro-immunity in parkinson's disease, Alzheimer's disease and stroke. Neuroimmunology and neuroinflammation 2016; 3(2):27-37.

41. Kalinderi K, Bostantjopoulou S, Katsarou Z, Fidani L. TLR9 -1237 T/C and TLR2 -194 to -174 del polymorphisms and the risk of Parkinson's disease in the Greek population: a pilot study. Neurol Sci 2013; 34(5):679-82.

42. Drouin-Ouellet J, St-Amour I, Saint-Pierre M, Lamontagne-Proulx J, Kriz J, Barker RA, Cicchetti F. Toll-like receptor expression in the blood and brain of patients and a mouse model of Parkinson's disease. Int J Neuropsychopharmacol 2014; 18(6).

43. Fellner L, Irschick R, Schanda K, Reindl M, Klimaschewski L, Poewe W, Wenning GK, Stefanova N. Toll-like receptor 4 is required for alpha-synuclein dependent activation of microglia and astroglia. Glia 2013; 61(3):349-60.

44. Noelker C, Morel L, Lescot T, Osterloh A, Alvarez-Fischer D, Breloer M, Henze C, Depboylu C, Skrzydelski D, Michel PP, Dodel RC, Lu L, Hirsch EC, Hunot S, Hartmann A. Toll like receptor 4 mediates cell death in a mouse MPTP model of Parkinson disease. Sci Rep 2013; 3:1393. 
45. Campolo M, Paterniti I, Siracusa R, Filippone A, Esposito E, Cuzzocrea S. TLR4 absence reduces neuroinflammation and inflammasome activation in Parkinson's diseases in vivo model. Brain Behav Immun 2019; 76:236-47.

46. Stefanova N, Fellner L, Reindl M, Masliah E, Poewe W, Wenning GK. Toll-like receptor 4 promotes alpha-synuclein clearance and survival of nigral dopaminergic neurons. Am J Pathol 2011; 179(2):954-63.

47. Mariucci G, Pagiotti R, Galli F, Romani L, Conte C. The Potential Role of Toll-Like Receptor 4 in Medi ating Dopaminergic Cell Loss and Alpha-Synuclein Expression in the Acute MPTP Mouse Model of Parkinson's Disease. J Mol Neurosci 2018; 64(4):611-18.

48. Ros-Bernal F, Hunot S, Herrero MT, Parnadeau S, Corvol JC, Lu L, Alvarez-Fischer D, Carrillo-de Sauvage MA, Saurini F, Coussieu C, Kinugawa K, Prigent A, Hoglinger G, Hamon M, Tronche F, Hirsch EC, Vyas S. Microglial glucocorticoid recep tors play a pivotal role in regulating dopaminergic neurodegeneration in parkinsonism. Proc Natl Acad Sci U S A 2011; 108(16):6632-7.

49. Maatouk L, Compagnion AC, Sauvage MC, Bemel mans AP, Leclere-Turbant S, Cirotteau V, Tohme M, Beke A, Trichet M, Bazin V, Trawick BN, Ransohoff RM, Tronche F, Manoury B, Vyas S. TLR9 activation via microglial glucocorticoid receptors contributes to degeneration of midbrain dopamine neurons. Nat Commun 2018; 9(1):2450.

50. Gao W, Xiong Y, Li Q, Yang H. Inhibition of Toll-Like Receptor Signaling as a Promising Thera py for Inflammatory Diseases: A Journey from Molecular to Nano Therapeutics. Front Physiol 2017; 8:508.

51. Hughes CD, Choi ML, Ryten M, Hopkins L, Drews A, Botia JA, Iljina M, Rodrigues M, Gagliano SA, Gandhi S, Bryant C, Klenerman D. Picomolar concentrations of oligomeric alpha-synuclein sensi tizes TLR4 to play an initiating role in Parkinson's disease pathogenesis. Acta Neuropathol 2019; 137(1):103-20.
52. Daniele SG, Beraud D, Davenport C, Cheng K, Yin H, Maguire-Zeiss KA. Activation of MyD88-depen dent TLR1/2 signaling by misfolded alpha-synucle in, a protein linked to neurodegenerative disorders.

Sci Signal 2015; 8(376):ra45.

53. Dasu MR, Riosvelasco AC, Jialal I. Candesartan inhibits Toll-like receptor expression and activity both in vitro and in vivo. Atherosclerosis 2009; 202(1):76-83.

54. Ping Z, Xiaomu W, Xufang X, Liang S. Vinpocetine regulates levels of circulating TLRs in Parkinson's disease patients. Neurol Sci 2019; 40(1):113-20.

55. Yan J, Qiao L, Tian J, Liu A, Wu J, Huang J, Shen M, Lai X. Effect of statins on Parkinson's disease: A systematic review and meta-analysis. Medicine (Baltimore) 2019; 98(12):e14852.

56. Yan JQ, Sun JC, Zhai MM, Cheng LN, Bai XL, Feng CL. Lovastatin induces neuroprotection by inhibiting inflammatory cytokines in 6-hydroxydopamine treated microglia cells. Int J Clin Exp Med 2015; 8(6):9030-7.

57. Peng Y, Zhang X, Zhang T, Grace PM, Li H, Wang Y, Li H, Chen H, Watkins LR, Hutchinson MR, Yin H, Wang X. Lovastatin inhibits Toll-like receptor 4 signaling in microglia by targeting its co-receptor myeloid differentiation protein 2 and attenuates neuropathic pain. Brain Behav Immun 2019; $82: 432-44$

58. Molteni M, Bosi A, Rossetti C. Natural Products with Toll-Like Receptor 4 Antagonist Activity. Int J Inflam 2018; 2018:2859135.

59. Yu Z, Wan Y, Liu Y, Yang J, Li L, Zhang W. Curcum in induced apoptosis via PI3K/Akt-signalling pathways in SKOV3 cells. Pharm Biol 2016; 54(10):2026-32.

60. Zeng KW, Zhang T, Fu H, Liu GX, Wang XM. Schisandrin B exerts anti-neuroinflammatory activi ty by inhibiting the Toll-like receptor 4-dependent MyD88/IKK/NF-kappaB signaling pathway in lipopolysaccharide-induced microglia. Eur J Pharmacol 2012; 692(1-3):29-37. 